\title{
Mustela putorius
}

National Cancer Institute

\section{Source}

National Cancer Institute. Mustela putorius. NCI Thesaurus. Code C77097.

A small domestic mammal of the type Mustela putorious, with an elong ated body and brown, black, white, or mixed fur. The ferret is carnivorous and crepuscular, spending 1418 hours a day sleeping. This animal is prone to adrenal cancers, insulinoma, and lymphoma. In pre-clinical research, the ferret is used most commonly in toxicological screening and studies involving human influenza virus, as well as studies in reproductive physiology, anatomy, endocrinology and neuroscience. 